\title{
Loss Firms' Annual Report Narratives and Share Price Anticipation of Earnings
}

Thomas Schleicher,

Khaled Hussainey,

and

Martin Walker

* The authors are based at the Manchester Accounting \& Finance Group, Manchester Business School, The University of Manchester, UK. They would like to thank the participants of the Corporate Information Disclosure and News Management Conference at Exeter University, the British Accounting Association Annual Conference at Heriot-Watt University and the 9th Financial Reporting and Business Communication Conference at Cardiff Business School. We are particularly grateful to Richard Jackson, Richard Taffler and two anonymous referees for helpful comments on earlier versions. Hussainey and Walker gratefully acknowledge the financial support from the ESRC (Grant Number RES-000-23-0962). Correspondence should be addressed to Professor Martin Walker, Manchester Accounting \& Finance Group, Manchester Business School, The University of Manchester, Booth Street West, Manchester, M15 6PB, UK. Email: martin.walker@manchester.ac.uk. 


\begin{abstract}
We extend prior research into the association between disclosure quality and share price anticipation of earnings by discriminating between firms that report profits and firms that report losses. As a measure of disclosure quality we count the number of forward-looking profit statements in annual report narratives. To measure the extent to which current share price movements anticipate future earnings changes we regress current stock returns on current and future earnings changes. The coefficients on the future earnings change variables are our measure of share price anticipation of earnings.

Our regression results show that the association between annual report narratives and share price anticipation of earnings is not the same for profit and loss firms. For loss firms we find that the ability of stock returns to anticipate next period's earnings change is significantly greater when the firm provides a large number of profit predictions in annual report narratives. We make no such observation for profit firms. In addition, once we control for variations in the intrinsic leadlag relation between returns and earnings across industries, the observed difference between profit and loss firms becomes statistically significant. Overall, our results are consistent with annual report narratives being a particularly important source of information for loss-making firms.
\end{abstract}




\section{Introduction}

Considerable attention has recently been given to the association between a firm's disclosure quality and the strength of the relation between current share price movements and future earnings changes (e.g. Lundholm and Myers, 2002; Gelb and Zarowin, 2002; Hussainey et al., 2003). A consistent finding across all studies is that the ability of stock returns to anticipate future earnings changes is significantly greater when the firm voluntarily provides higher levels of disclosure. The present paper adds to this literature by examining whether the association between annual report narratives and share price anticipation of earnings varies between firms reporting profits and firms reporting losses.

There are two reasons why one might expect annual report narratives to be a particularly important source of information for loss-making firms. First, because losses cannot prevail indefinitely in surviving firms the existence of a loss in such a firm unambiguously indicates that current income is not a good guide to the longer-term earnings power of the firm. Thus, in order to estimate future earnings investors in surviving firms need additional information which explains why the losses arise and when the firm will eliminate the losses in the future. Note that because bankruptcy is a relatively rare occasion among stock market listed companies, the argument of losses not being indicative of the future applies to all but a small minority of loss firms in our sample.

Second, previous evidence in Hayn (1995) finds that the strength of the relation between annual stock returns and same-period earnings changes is considerably lower for loss-making firms than for profitable firms. This evidence suggests that in the short-term the market is responding more strongly to non-earnings information. The joint question we consider in this paper is whether such non-earnings information is included in annual report narratives, and whether it helps stock returns to anticipate future earnings changes. While the empirical evidence in Hayn (1995), 
strictly speaking, only supports the notion that loss firms' current stock returns contain a higher proportion of non-earnings information, it is natural to expect this value-relevant non-earnings information to be reflected, sooner or later, also in reported earnings.

To measure the quality of a firm's non-earnings information we count the number of forwardlooking profit statements in annual report narratives. To measure the extent to which current share price movements anticipate future earnings changes we follow Collins et al. (1994) and regress current stock returns on current and future earnings changes. The coefficients on the future earnings change variables are our measure of share price anticipation of earnings.

Our regression results show that the association between annual report narratives and share price anticipation of earnings is not the same for profit and loss firms. For loss firms we find that the ability of stock returns to anticipate next period's earnings change is significantly greater when the firm provides a large number of profit predictions in annual report narratives. We make no such observation for profit firms. In addition, once we control for variations in the intrinsic leadlag relation between returns and earnings across industries, the observed difference between profit and loss firms becomes statistically significant.

The remainder of the paper is organised as follows. The next section discusses the relevant literature and develops our empirical hypothesis. Section 3 describes the way we measure the quality of disclosure in annual report narratives. Empirical models of share price anticipation of earnings are discussed in Section 4. Section 5 describes the data, and we present our regression results in Section 6. Section 7 summarises and suggests areas for further research. 


\section{Literature Review and Hypothesis}

We begin our literature review by discussing empirical studies that are concerned with the usefulness and predictive value of annual report narratives. One such study is Clarkson et al. (1999) which examines whether the Management Discussion and Analysis (MD\&A) section of the annual report is useful to sell-side analysts. The responses from analysts suggest that narrative disclosures in MD\&As are indeed used for financial analysis purposes, and that MD\&A narratives provide information incremental to both that included in financial statements and that available from sources outside the annual report (e.g. press releases). A content analysis subsequently reveals that it is in particular the forward-looking area of the MD\&A that includes large amounts of non-stale information.

In a related study Clarkson et al. (1994) explicitly look at forward-looking information. Their study searches the MD\&As of a sample of large listed Canadian companies for directional forecasts of net income, cash flow and sales, and compares the predictions with actual outcomes. Of 274 firms which forecast a change in operating performance for the next year 195 predict correctly. This leads to a rejection of the null hypothesis of independence between predicted and actual outcome. Thus, Clarkson et al. (1994) provide evidence that voluntary MD\&A forecasts have information content for future financial performance. Similar evidence on directional earnings forecasts is available in Steele (1982) for the chairman's statement.

A number of studies also examine the ability of annual report narratives to predict a firm's future financial status (e.g. Tennyson et al., 1990; Smith and Taffler, 2000). Smith and Taffler (2000), for example, explore the association between discretionary narrative disclosures in the chairman's statement and subsequent corporate failure. Employing linear discriminant analysis their study is able to correctly classify 65 out of 66 failed and non-failed firms with a seven variable word-based model. Thus, Smith and Taffler (2000) provide evidence that unaudited 
managerial disclosures in the chairman's statement contain important information which is highly associated with a firm's future financial status.

Another study of interest is that of Bryan (1997). Bryan (1997) analyses the information content of four backward-looking and three forward-looking MD\&A disclosures mandated by the Securities Exchange Commission. He finds that a discussion of future operations is significantly associated with one-period ahead changes in eps, sales and capital expenditures, but longer-term associations are generally not significant. In a separate test Bryan (1997) also regresses shortwindow announcement returns on the seven disclosure variables, but finds a significant association with abnormal returns only for planned capital expenditures.

Since Bryan (1997) a number of studies have examined the effects of corporate disclosure on forecasting accuracy and current valuation within a single model. An early such study is Schleicher and Walker (1999). Schleicher and Walker draw on the ideas in Kothari (1992) and predict that the anticipated portion of current period earnings change is greater for high disclosure firm-years. To test this prediction they regress current period returns on current period earnings change and allow the earnings change coefficient to vary with lagged disclosure quality. As predicted they find that the slope coefficient on current earnings is significantly lower for firms with a larger number of forward-looking statements in the annual report discussion section. This observation is consistent with the surprise element in current earnings being lower for firms with strong disclosures in prior years.

Subsequent papers on disclosure and the return-earnings relation have motivated their tests in a similar way to Schleicher and Walker (1999), but have tended to focus their attention more on the effect of disclosure on the relation between current returns and future earnings. Those studies include Lundholm and Myers (2002), Gelb and Zarowin (2002) and Hussainey et al. (2003). All 
three studies follow Collins et al. (1994) and augment the standard return-earnings relation by adding future years' earnings variables into the regression model. They then hypothesise that the market's ability to adjust current prices in line with future earnings changes increases with more forthcoming disclosures. Using AIMR-FAF ratings to measure the quality of a firm's information environment, Lundholm and Myers (2002) and Gelb and Zarowin (2002) find evidence that higher levels of corporate disclosure are indeed associated with a stronger relation between current share price movements and future earnings changes. A similar observation is made in Hussainey et al. (2003) with a disclosure metric based on annual report narratives. However, none of the above papers makes any attempt at discriminating between profit and loss firms. Therefore, in the current paper we ask whether the association between annual report narratives and share price anticipation of earnings differs between firms reporting profits and firms reporting losses. ${ }^{1}$

Our decision to distinguish between profit and loss firms can perhaps be best explained in the context of the permanent earnings model. In this model permanent earnings is defined as the perpetuity which - when multiplied by $\frac{1+r}{r}$ where $r$ is the required rate of return on equity yields the firm's current share price. With share prices and multipliers both being non-negative by definition permanent earnings must be non-negative too.

The permanent earnings model helps to illustrate two limitations of reported earnings in lossmaking years. First, the presence of an accounting loss indicates that reported income cannot be a

\footnotetext{
${ }^{1}$ The literature review above focuses largely on studies which examine the information content of corporate disclosures for future reported earnings, with particular attention being given to studies of annual report narratives. A number of other studies examine related issues: (1) Barron et al. (1999) provide evidence that high ratings of MD\&A disclosures are associated with less error and less dispersion in analyst earnings forecasts. (2) Botosan (1997) shows that the quality of annual report disclosures is inversely related to a firm's cost of equity capital. (3) Forward-looking earnings statements in a turnaround scenario are value-relevant (Miller and Piotroski, 2000), but otherwise positive earnings forecasts are value-relevant only when supplemented by verifiable forward-looking statements (Hutton et al., 2003).
} 
reliable guide to the longer-term earnings power of a surviving firm as only profits are sustainable in the long-run. Second, the presence of a loss means that the market cannot price the firm on the basis of reported earnings as such a valuation would imply a negative share price (which is inconsistent with the limited liability feature of shares).

Thus, when valuing (surviving) loss firms the market has to look behind the reported loss to find indicators of how long the losses are likely to continue, and to estimate what the longer-run earnings-generating capacity of the firm will be once it returns to profits. The market will be aware that there are a number of possible reasons for reported losses including a fall in sales, higher operating costs, over-depreciation of tangible assets, or the immediate expensing of intangibles. Moreover, the market will understand that the persistence of losses depends very much on the precise cause of the loss. Investors may be fairly relaxed about a firm that reports a loss if it knows that this is due to the expensing of major investments in intangibles and if there are good signs that these investments are achieving profits over the coming years. On the other hand the presence of a loss associated with a fall in sales could well herald a fundamental change for the worse in the firm's earnings-generating capacity over the short and medium term, in which case the share price consequences will be severe. In order to differentiate between the various scenarios the market obviously requires information in addition to current earnings. We investigate whether part of this additional information is included in annual report narratives.

Previous empirical evidence also supports the view that additional explanations might well be especially relevant in loss-making years. For example, Hayn (1995) finds a marked difference in the results of a regression of annual stock returns on current earnings change between profitable firms and loss-making firms. For profitable firms she finds an earnings response coefficient of 2.64 and an adjusted $\mathrm{R}^{2}$ of $13.7 \%$. For loss-making firms the corresponding values are much lower at 0.50 and $3.7 \%$, respectively. These values suggest that the information content of 
current earnings for current period returns is substantially lower in loss-making years. This, however, implies that the market is reacting more strongly to non-earnings information. The joint question we consider in this paper is whether such non-earnings information is included in annual report narratives, and whether it helps stock returns to anticipate future earnings changes.

Building on the findings in Hayn (1995), Ertimur (2004) examines whether a decrease in the value-relevance of accounting numbers in loss-making years translates into higher levels of information asymmetry among investors. Using bid-ask spreads as a proxy for the level of information asymmetry she finds that loss firms indeed experience a higher bid-ask spread than profit firms. In her conclusion Ertimur (2004) speculates that loss-making firms might well be able to reduce the spread through the provision of additional voluntary information.

The current paper looks at the effect of disclosure on information efficiency in the context of share price anticipation of earnings. We focus on loss-making firms because theoretical and empirical arguments suggest that investors of loss-making firms have a special need for additional disclosures. To measure disclosure we count the number of statements about future profits in annual report narratives. Empirical evidence in Steele (1982), Clarkson et al. (1994) and Hussainey et al. (2003) suggests that this type of information is associated with future earnings changes. Thus, we formally test the following null hypothesis:

$\mathbf{H}_{\mathbf{0}}$ The association between share price anticipation of earnings and the number of profit predictions in annual report narratives is the same for profit and loss firms.

We formulate $\mathrm{H}_{0}$ in the null form and not in the alternative form because it is also possible that narratives are actually less (rather than more) informative in loss-making years. In particular, there is evidence that managers provide self-serving disclosures that blame poor performance 
excessively on (temporary) external factors. Such tendencies have been documented both for annual report narratives (e.g. Lennox, 2001; Clatworthy, and Jones, 2003) and for attributions associated with earnings forecasts (Baginski, Hassell and Hillison, 2000; Baginski, Hassell and Kimbrough, 2004). While market reaction tests in Baginski, Hassell and Hillison (2000) and Baginski, Hassell and Kimbrough (2004) suggest that the attribution bias, on average, is not large enough to reduce the usefulness of earning forecasts, it is still possible that in our sample these reporting patterns lead to profit predictions that are less informative when companies are performing poorly.

In order to test $\mathrm{H}_{0}$ we need a measure of the number of profit predictions in annual report narratives and a measure of the extent to which share prices anticipate future earnings changes. The next two sections develop these two measures.

\section{Disclosure Scores}

In order to study the disclosure decisions of large samples of loss-making and profitable firms we need a low-cost method of evaluating the quality of disclosures in annual report narratives. Automating the generation of disclosure scores through the use of a computer program is one way to achieve this. Several previous studies have employed such programs in the analysis of accounting narratives (e.g. Frazier et al., 1984; Abrahamson and Amir, 1996). For example, Abrahamson and Amir (1996) develop their own program to identify the (relative) number of words with negative connotations in large samples of president's letters. They find that this metric is negatively associated with accounting-based performance measures and with marketadjusted returns. A common feature of studies that employ computer programs is that they rely on frequency counts of words to produce measures of disclosure quality. The advantage of frequency counts is that they can be generated at relatively low costs. This makes the task of evaluating the disclosure quality of large samples of firms manageable. 
Our study follows the scoring technique recently developed in Hussainey et al. (2003). Their study produces frequency scores through the use of the text analysis package Nudist. Hussainey et al. (2003) develop their scores in three successive steps. First, they identify key words that are associated with future-orientated statements in the annual report discussion section. Second, they identify topics that reflect a discussion of the firm's future in analyst reports. Finally, they produce a measure of disclosure quality by counting sentences that are both forward-looking and include a relevant topic. The following paragraphs provide a brief summary of the relevant steps in Hussainey et al. (2003).

Hussainey et al. (2003) start the derivation of their disclosure scores by producing a list of key words that are - in most cases - associated with forward-looking statements in annual report narratives. To draw up an initial list of key words they read a number of annual reports and make note of any key word that is associated with forecasts and predictions. They then consult the Thesaurus dictionary for any synonyms of those key words and add these synonyms to the initial list. Finally, for each initial key word they draw a random sample of thirty sentences from annual report narratives. Forward-looking key words are included in the final list if at least twenty of the thirty sentences refer to the future. The final list of key words includes verbs like 'anticipate', 'expect' and 'forecast', nouns like 'outlook' and 'prospect' and adjectives like 'novel' and 'optimistic'. For the purpose of this study we use the same list of 35 forward-looking key words as in Hussainey et al. (2003). ${ }^{2}$

\footnotetext{
${ }^{2}$ The complete list of 35 forward-looking key words is as follows: accelerate, anticipate, await, coming (financial) year(s), coming months, confidence (or confident), convince, (current) financial year, envisage, estimate, eventual, expect, forecast, forthcoming, hope, intend (or intention), likely (or unlikely), look forward (or look ahead), next, novel, optimistic, outlook, planned (or planning), predict, prospect, remain, renew, scope for (or scope to), shall, shortly, should, soon, will, well placed (or well positioned), year(s) ahead. In line with Hussainey et al. (2003) we also include future year numbers in the list of forward-looking key words.
} 
The next step in the derivation of the disclosure scores is the identification of informational items that are relevant to the capital market in assessing the firm's future. Because the capital market's information set is unobservable Hussainey et al. (2003) examine the contents of analyst reports from a wide range of industry sectors as a substitute. For each forward-looking sentence in the analyst report they identify the main theme of the discussion by selecting the key noun of that sentence. This results in a comprehensive list of 500 themes. The list reflects items from the financial statements, but also a discussion of economy-wide factors, industry trends and industryspecific performance measures. From this comprehensive list of 500 themes they also construct a number of 'special' topic lists that reflect only a discussion of individual line items in the profit and loss account. It is the topic list that is related to profits that we use to test $\mathrm{H}_{0}$. This list comprises the words 'benefit', 'breakeven', 'budget', 'contribution', 'earnings', 'eps', 'loss', 'margin', 'profit', 'profitability', 'return' and 'trading'.

Using Nudist we text-search annual report narratives for sentences that include both a forwardlooking key word and a noun related to profits. This is done by finding the intersection of the key word search and the topic search. The resulting disclosure metric is an attempt to count the number of forward-looking profit statements in a firm's annual report discussion section.

Using the above disclosure metric has a number of advantages. First, the disclosure scores can be produced at minimal costs and hence are a feasible alternative to labour-intensive reading for sample sizes that contain several thousands of observations. Second, the resulting metric narrowly matches the intuition behind $\mathrm{H}_{0}$. In particular, it only emphasises management's statements about the future, thus abstracting from backward-looking review sections that presumably are much less relevant on average in predicting future firm performance. Also, by focusing only on profit topics - the line item in the profit and loss account that is of most relevance to $\mathrm{H}_{0}$ - we try to reduce the noise element inherent in our disclosure scores. Finally, by 
using analyst reports as a reference point we try to link our disclosure scores directly to the market's ability to predict and value firm performance.

A potential limitation of our disclosure scores is that they are biased towards a 'form orientated' approach to content analysis (e.g. Smith and Taffler, 2000; Clatworthy and Jones, 2003). In particular, simply adding up the number of statements in a mechanical way is likely to lead to a noisy measure of disclosure quality. Noise can result, for example, from the common practice among UK firms to include identical (or similar) statements in two different places within the annual report discussion section. Pre-empting subsequent statements about future profits (in the highlight section, for example) should not change the predictive value of annual report narratives, but will often increase the disclosure score for a firm that follows this practice. Unfortunately, avoiding this type of noise would require a completely different research design, one that is based on labour-intensive reading. Instead, we follow previous disclosure studies like Gelb and Zarowin (2002) and Hussainey et al. (2003) and try to increase the power of our test by deleting firms with disclosure scores in the middle range. Effectively, our main regression results will compare firms with no or hardly any profit predictions against firms with a large number of profit predictions. This is exactly the scenario where the effect of disclosure on prices leading earnings is most likely to be detectable empirically (if it does exist). Given the potential for noise in our disclosure metric we do not feel it would be appropriate to compare firms with, say, a disclosure score of four against firms with a disclosure score of five. Nonetheless, for the sake of completeness we also present results based on the full sample in Section 6. We now turn to a discussion of our measure for share price anticipation of earnings.

\section{Share Price Anticipation of Earnings}

We use the model of Collins et al. (1994) to detect share price anticipation of earnings. In order to capture the concept of share price anticipation Collins et al. (1994) add three years of future 
earnings growth variables to the simple return-earnings model along with a number of control variables. The inclusion of these additional variables yields the augmented return-earnings regression model in Equation (1):

$$
R_{t}=b_{0}+b_{1} X_{t}+\sum_{k=1}^{3} b_{k+1} X_{t+k}+\sum_{k=1}^{3} b_{k+4} R_{t+k}+b_{8} E P_{t-1}+b_{9} A G_{t}+e_{t}
$$

where $R_{t}$ is the stock return for year $t$ and $R_{t+1}, R_{t+2}$ and $R_{t+3}$ are the stock returns for the years $t+1, t+2$ and $t+3$, respectively. $X_{t}$ is period $t$ 's earnings growth rate while $X_{t+1}, X_{t+2}$ and $X_{t+3}$ are the three future earnings growth variables. $E P_{t-1}$ is defined as the earnings level in period $t-1$ over price at the start of period $t$, while $A G_{t}$ is the growth rate of total book value of assets in period $t$.

To understand the logic behind Equation (1) it is useful to start from the simple regression model of returns on current period's earnings growth as given in Equation (2):

$R_{t}=b_{0}+b_{1} X_{t}+e_{t}$

Equation (2) states that returns in period $t$ are only a function of earnings growth in period $t$. Under ideal conditions Equation (2) will yield a perfect fit with an $R^{2}$ of $100 \%$ and an earnings response coefficient, $b_{1}$, of $\frac{1+r}{r}$ where $r$ is the required rate of return on equity. ${ }^{3}$ However, when the market has access to value-relevant information other than earnings, then the explanatory power of Equation (2) will be less than $100 \%$ and the earnings response coefficient will be downward biased. The purpose of the augmented Collins et al. (1994) model in Equation

\footnotetext{
${ }^{3}$ Ideal conditions require that (1) the market is semi-strong efficient, (2) earnings follow a random walk, and (3) current period earnings capture all value-relevant information available at that time.
} 
(1) is to allow for the existence of value-relevant non-earnings information (such as profit predictions in accounting narratives). This requires a number of adjustments to be made to Equation (2).

First, a portion of period $t$ 's earnings change might have been anticipated in a previous period. This means that the earnings growth variable no longer accurately measures the period $t$ 's earnings surprise because total earnings growth now includes both an anticipated and a surprise element. In order to control for the anticipated portion of current period's earnings growth Collins et al. (1994) add to the regression model (2) two proxies for the market's earnings expectations at the end of the period $t-1$. These are earnings yield, $E P_{t-1}$, and asset growth, $A G_{t}{ }^{4}$

Second, with non-earnings information being available to the market place, the current period's earnings surprise is no longer a reliable measure of the market's revision in future earnings expectations. ${ }^{5}$ To account explicitly for those revisions Collins et al. (1994) include three years of realised future earnings growth variables in (1). Including three years is consistent with previous research in Kothari and Sloan (1992) which demonstrates that the empirically detectable lead-lag relation between returns and earnings is no more than three years. The earnings yield variable, $E P_{t-1}$, and the asset growth variable, $A G_{t}$, once again control for the portions of future realised earnings growth rates that have been anticipated at $t-1$, while the inclusion of future

\footnotetext{
${ }^{4}$ If the market expects high earnings growth for period $t$, then this will be reflected in a higher price at the start of period $t$ relative to last year's earnings. Thus earnings yield and period $t$ 's expected earnings growth rate are inversely related. The asset growth variable reflects changes in the firm's production capacity. Additional investment should lead the market to expect higher earnings growth in period $t$. Collins et al. (1994) use asset growth in period $t$ rather than asset growth in $t-1$. While not explicitly discussed in Collins et al. (1994), a possible reason is that it is the announcement of the firm's decision to invest rather than the actual addition of tangible fixed assets to the balance sheet that leads the market to revise next period's earnings expectations. However, in the context of large samples it is easier to collect the data on the subsequent additions. Thus, Equation (1) appears to assume that the time to build is around one year.

${ }^{5}$ For example, it is quite possible for an announcement of a surprise loss to be accompanied by a positive (and credible) trading statement from the firm's management.
} 
returns variables, $R_{t+k}$, controls for the news about future earnings growth rates received after period $t .^{6}$

We make three changes to the original model of Collins et al. (1994). First, we include only two years of future earnings growth variables in our regression model. This is done to preserve a maximum number of observations for our sample of loss-making firms. This sample is much smaller than the sample of profitable firms, and requiring only two (rather than three) years of future earnings and return variables increases the number of loss observations with a complete set of regression variables (from 533) to $857 .^{7}$ Second, in calculating the current and future earnings growth variables we deflate earnings change by price and not by lagged earnings because earnings of loss firms are an unreliable deflator for next period's earnings growth rate. Finally, we exclude the earnings yield variable, $E P_{t-1}$, from the regression model because there is evidence that this variable is a poor control variable for loss-making firms. For these firms the coefficient on the earnings yield variable is significantly negative, and loss firms' coefficients on current and future earnings change are now substantially lower, inconsistent with the nature of a control variable in the Collins et al. (1994) model.

The main question we address in this paper is whether the effect of disclosure on share price anticipation of earnings is the same for profit and loss firms. To examine this issue we define two 0/1 dummy variables, one for disclosure quality and one for the existence of a loss. We then

\footnotetext{
${ }^{6}$ For example, the return in period $t+1, R_{t+1}$, should reflect both the unanticipated portion of period $t+1$ 's earnings growth rate as well as period $t+1$ 's revisions in expected earnings growth rates that relate to earnings beyond $t+1$. Generally, unanticipated future events that lead to higher (lower) earnings growth rates should also lead to positive (negative) returns in the period when news becomes available to the market. Hence, a positive relation between future unexpected earnings and future returns is expected to result in negative coefficients on the return variables. This is true because measurement error proxies serve to subtract the noise element from realised earnings growth rates.

${ }^{7}$ In our sample the two-year survival rates are broadly comparable across profit and loss firms: $76 \%$ and $68 \%$ respectively. However, loss firms only account for $19 \%$ of all firm-years in our sample, thus making a high survival rate more important for the subsample of loss-making firms. Note that the proportion of loss-making firm-years in our sample is virtually identical to that reported in Hayn (1995). Thus, while profit observations dominate loss observations by approximately 4 to 1 , losses are by no means uncommon.
} 
allow the intercept and the coefficients on the three earnings variables in the (modified) Collins et al. (1994) model to vary across profit and loss firms and between high and loss disclosure firms. This produces our main regression model (3):

$$
\begin{aligned}
& R_{t}=b_{0}+b_{1} X_{t}+b_{2} X_{t+1}+b_{3} X_{t+2}+b_{4} R_{t+1}+b_{5} R_{t+2}+b_{6} A G_{t}+b_{7} \text { LOSS }+b_{8} \text { LOSS * } X_{t} \\
& +b_{9} \operatorname{LOSS}^{*} X_{t+1}+b_{10} \operatorname{LOSS}^{*} X_{t+2}+b_{11} D+b_{12} D * X_{t}+b_{13} D * X_{t+1}+b_{14} D * X_{t+2} \\
& +b_{15} D * \operatorname{LOSS}+b_{16} D * \operatorname{LOSS} * X_{t}+b_{17} D * \operatorname{LOSS} * X_{t+1}+b_{18} D * \operatorname{LOSS} * X_{t+2}+e_{t}
\end{aligned}
$$

In Equation (3) LOSS is defined as 1 (0) for firms with negative (positive) income in period $t$, while $D$ is set equal to $1(0)$ for firm-years with a high (low) number of profit predictions. With these definitions the coefficients on $X_{t+1}$ and $X_{t+2}$ measure share price anticipation of earnings one year and two years ahead for low disclosure profit firms. If profit predictions in the annual reports of profit firms change the ability of stock returns to anticipate future earnings changes, then we would expect significant coefficients on $D^{*} X_{t+1}$ and $D^{*} X_{t+2}$. Finally, if the association between disclosure and share price anticipation of earnings is statistically different for profit and loss firms, then we would expect significant coefficients on $D^{*} L O S S * X_{t+1}$ and $D * \operatorname{LOSS} * X_{t+2} \cdot{ }^{8}$

\section{Data}

In order to use Nudist as a text analysis tool we need annual reports in a computer-readable format. Large cross-sections of computer-readable UK annual reports are available on Dialog for

\footnotetext{
${ }^{8}$ We also estimated a regression model where the intercept and all six regressors of the (modified) Collins et al. (1994) model are allowed to vary with disclosure quality and between profit and loss firms. Of the additional nine interaction terms associated with future returns and asset growth, only two are significant, and crucially, the remaining nineteen coefficient estimates are extremely similar to those reported in Section 6 below. We then added the earnings yield variable to this extended regression model. As reported in the main text we find that the earnings yield coefficient is significantly negative for the group of loss-making firms and that loss firms' current and future earnings response coefficients are now substantially lower than those reported in Section 6. However, the findings in relation to the coefficients on $D^{*} L O S S^{*} X_{t+1}$ and $D^{*} L O S S^{*} X_{t+2}$ are qualitatively similar to those reported below. Thus, the main findings of our paper are unaffected by the exclusion of the earnings yield variable from regression model (3).
} 
the years 1996 to $2002 .{ }^{9}$ The total number of annual reports on Dialog for these seven years is 11,756. After removing financial companies this reduces to 8,098 . Of those 7,977 firm-years have a matching record on Datastream.

Subsequently, we delete 727 observations because of changing year-ends, while regression variables are missing for 2,154 observations. We also remove a total of 528 outliers defined as observations falling into the top or bottom $1 \%$ of any of the seven regression variables. In defining outliers we treat profit and loss observations as separate distributions. Otherwise, a disproportionately large number of loss observations falls into the top and bottom $1 \%$. Finally, in order to increase the spread between high and low disclosure firm-years we delete a total of 2,122 observations with disclosure scores in the second and third quartiles of the two distributions of disclosure scores. Defining the middle ranges separately for profit and loss firms makes sure that we have a sufficient number of loss firms which are classified as high disclosure observations. ${ }^{10}$ The above deletions leave us with a total of 2,446 observations for estimation. Of those $324(2,122)$ firm-years are loss-making (profit-making).

We define a loss (profit) as negative (positive) operating income before all (operating and nonoperating) exceptional items as given by Worldscope item 01250. We use operating income to separate loss from profit firms because we feel that this line item best matches the nature of the trading statements included in our profit forecasts. These forecasts almost always refer to the operational side of the business. Statements about financial aspects or taxation are extremely rare. We exclude exceptional items from our definition of operating income because their transitory nature is clear from the face of the profit and loss account. For example, the predictive

\footnotetext{
${ }^{9}$ Dialog was discontinued by Thomson Financial in mid-2004. The year 2002 is the last year with a comprehensive coverage.

${ }^{10}$ When we pool profit and loss firms and delete observations with disclosure scores in the two middle quartiles, then relatively few loss firms end up as high disclosure observations. This is due to (1) loss firms having a lower average disclosure score than profit firms, and (2) profit firms dominating loss firms by approximately 4 to 1.
} 
value of accounting narratives is likely to be much smaller in situations where the operating loss is caused by an exceptional operating cost.

We collect all regression variables from Datastream. Our earnings measure is once again Worldscope item 01250 which is operating income before all exceptional items. ${ }^{11} \mathrm{We}$ convert total earnings into earnings per share by dividing item 01250 by the outstanding number of shares (corrected to account for bonus and rights issues). ${ }^{12} X_{t}, X_{t+1}$ and $X_{t+2}$ are then defined as earnings change for the periods $t, t+1$ and $t+2$ deflated by price. Both current and future earnings changes are deflated by the share price at the start of the return window for period $t$ (see Lundholm and Myers (2002) for a justification). Returns, $R_{t}, R_{t+1}$ and $R_{t+2}$, are calculated as buy-and-hold returns from eight months before the financial year-end to four months after the financial year-end. Thus, the return window for period $t, R_{t}$, includes the market reaction to profit predictions as long as those narratives are released within four months of the financial year-end. ${ }^{13}$ Finally, $A G_{t}$ is defined as the growth rate of total book value of assets (Worldscope item 02999) for period $t$, while the disclosure dummy variable, $D$, is set equal to $1(0)$ for firms with a disclosure score in the top (bottom) quartile of the two distributions of disclosure scores.

Table 1 presents descriptive statistics. The two panels correspond to the two subsamples of lossmaking and profit-making firm-years. Not surprisingly, median return and median earnings change in period $t$ are negative for the subsample of loss-making firm-years. However, there is

\footnotetext{
${ }^{11}$ Gelb and Zarowin (2002) also use operating income in their regression model.

12 Previously, a standard measure of earning per share as used by a large number of UK researchers in returnearnings studies was Datastream item 183. This item was - in almost all cases - identical to 'headline earnings' as calculated in Lin and Walker (2000), but is now no longer available on Datastream. Datastream, however, provides a definition of eps derived from Worldscope items that it believes comes as close as possible to the old Datastream item 183. The Pearson correlation between this definition of eps and the measure of eps used in the present study is 0.94 , significant at the 0.001 level. We also calculated the correlation between our measure of eps and the old Datastream item 183 for 2,631 observations from the years 1996-99 for which we still have the old Datastream item 183 on file. The correlation is 0.77 with a p-value of 0.001 .

${ }^{13}$ The definition of the return window follows Hussainey et al. (2003). They look at the dates under the chairman statement and argue that the vast majority of annual reports in their sample is released within four months.
} 
also evidence that period $t$ 's median earnings decline is more than reversed in the following two years. Despite this reversal the median return in period $t+1$ continues to be negative for lossmaking firm-years. Finally, we observe a substantial difference in the frequency scores between high and low disclosure loss firms. Clearly, this is a result of our decision to delete observations in the second and third quartiles.

When looking at the sample statistics of profit-making firm-years we note that period $t$ 's median return and earnings change are now positive, as one would expect for this subsample, but there is no evidence of a reversal of the positive earnings change over the next two periods. However, the distribution of disclosure scores is similar to that of loss-making firm-years. In particular, the inter-quartile range of the full distribution (which includes the two middle quartiles) is 5 for both subsamples. Finally, we note that the median profit-making firm-year is almost five times as large in terms of total asset values as the median loss-making firm-year. In Section 6 we present results from a supplementary test which suggest that the differences in firm size are unlikely to explain our findings.

\section{[Table 1 about here]}

Table 2 presents Pearson correlations for the seven regression variables, total assets (as a proxy for firm size) and the disclosure scores. Correlations below (above) the diagonal correspond to the subsample of loss-making (profit-making) firm-years. P-values are given in parentheses.

We observe that for loss-making firm-years the correlation between period $t$ 's returns, $R_{t}$, and period $t$ 's deflated earnings change, $X_{t}$, is positive and highly significant, though perhaps not very high in economic terms. The same applies to the contemporaneous correlations between returns and earnings in period $t+1$ and $t+2$. However, there is no evidence that prices of loss- 
making firm-years anticipate future earnings changes. The two correlations between current period returns, $R_{t}$, and future earnings changes, $X_{t+1}$ and $X_{t+2}$, are close to zero and insignificant, and the same applies to the correlation between $R_{t+1}$ and $X_{t+2}$.

When looking at profit-making firm-years we note that the contemporaneous correlations between returns and earnings changes are, on average, twice as large as those of loss-making firm-years. Also, for profitable firm-years there is evidence of prices leading earnings by one period. The two correlations between returns in periods $t$ and $t+1$ and the following year's earnings change are 0.218 and 0.166 , both significant at the 0.001 level. There is at best weak evidence of prices leading earnings by two periods. The univariate correlation between $R_{t}$ and $X_{t+2}$ is 0.038 with a p-value of 0.079 .

\section{[Table 2 about here]}

The next section discusses the findings of the multivariate regression analysis. The regression framework adds value for at least two reasons. First - unlike Pearson correlations - it aims to extract that part of the earnings change that does not trigger returns in period $t$ and thus it is potentially more accurate. Second, the regression framework allows us to quantify the effect of disclosure quality on prices leading earnings. As the next section will show the average nature of the Pearson correlations hides some important differences between high and low disclosure loss firms.

\section{Regression Results}

Our first set of regression results is given in Table 3. The table reports parameter estimates for our main regression model (3) in Column (5). In addition, Table 3 presents results for three other 
regression models in Columns (2), (3) and (4). As will be clear from our discussion below all three additional models are nested within our main regression model (3). We report heteroscedasticity-consistent p-values in parentheses.

We start our discussion of Table 3 by commenting briefly on the results in Column (2). Column (2) contains parameter estimates for the (modified) Collins et al. (1994) model. The model in Column (2) is similar to the one in Equation (1), but excludes the earnings yield variable as well as earnings and return variables for period $t+3$. The (modified) Collins et al. (1994) model neither discriminates between profit and loss firms, nor does it allow the association between current stock returns and future earnings changes to vary with disclosure quality. Nonetheless, its results can serve as reference point for any subsequent discussion. We find that the parameter estimates on $X_{t}$ and $X_{t+1}$ are 1.16 and 0.66 and both estimates are significant at the 0.001 level. Thus, the (modified) Collins et al. (1994) model indicates that current stock price movements are positively associated with current earnings changes as well as next period's earnings changes. But there is no evidence of prices leading earnings by two periods. The coefficient on $X_{t+2}$ is close to zero and insignificant.

Column (3) extends the (modified) Collins et al. (1994) model by allowing the intercept and the three earnings change coefficients to vary across profit and loss firms. This extension is - to some extent - similar to the spirit in Hayn (1995), though Hayn (1995) only estimates a simple regression of returns on same-period earnings change. Like Hayn (1995) we find that there is a marked difference in the coefficient on the current earnings change variable between profit and loss firms, and our two estimates are very similar to hers. In particular, we find a coefficient of 2.31 for profit firms and 0.58 for loss firms. The difference between the two estimates of -1.73 is significant at the 0.001 level. 
Our novel finding in Column (3) relates to the difference in the association between current returns and future earnings changes across profit and loss firms (and this finding is consistent with the Pearson correlations in Table 2). For profit firms we find evidence of prices anticipating earnings one year and two years ahead, but there is no such anticipation for loss firms. In particular, for profit firms the coefficients on $X_{t+1}$ and $X_{t+2}$ are 1.52 and 0.65 , both significant at the 0.001 level. This contrasts with loss firms for which we observe insignificant values of 0.24 and $-0.24 .{ }^{14}$ We believe this is an interesting first observation because it suggests that stock returns are able to anticipate future earnings changes of profit firms, but not those of loss firms, and the p-values associated with $\operatorname{LOSS}^{*} X_{t+1}$ and $\operatorname{LOSS}^{*} X_{t+2}$ indicate that the differences between the two subsamples are highly significant.

The regression model in Column (4) allows the intercept and the earnings coefficients to vary with the level of disclosure quality (but not across profit and loss firms). This specification is similar to the regression models in Lundholm and Myers (2002), Gelb and Zarowin (2002) and Hussainey et al. (2003). We make a number of observations that are consistent with the prior evidence. First, the coefficient on $X_{t+1}$ is no longer significant. This means that there is no significant association between current stock returns and next period's earnings change for firms with no (or few) profit predictions in the annual report discussion section. Second, for high disclosure firm-years we find that the association between current stock returns and next period's earnings change $i s$ significant. The sum of the coefficients on $X_{t+1}$ and $D^{*} X_{t+1}$ is 0.94 and the associated p-value is 0.001 (not reported in Table 3). However, the difference in the return-nextperiod-earnings association between the two groups is not significant. The p-value associated with $D^{*} X_{t+1}$ is 0.159 . Finally, we note that the coefficient on $D^{*} X_{t+2}$ is close to zero and highly insignificant. This is consistent with the evidence in Hussainey et al. (2003).

\footnotetext{
${ }^{14}$ The two values are calculated as $0.24=1.52-1.28$ and $-0.24=0.65-0.89$. The p-values associated with these two sums are 0.256 and 0.478 (not reported in Table 3).
} 
The results for our main regression model (3) are reported in Column (5). As discussed in detail in Section 4 this model allows the intercept and the earnings coefficients to vary with disclosure and with the sign of current year's income. Looking first at the coefficients of low disclosure profit firms we observe that the coefficients on $X_{t+1}$ and $X_{t+2}$ of 1.44 and 0.71 are very similar to the corresponding 'all profit firm' coefficients in Column (3). At the same time the incremental effect of disclosure on profit firms is close to zero and insignificant. The coefficients on $D^{*} X_{t+1}$ and $D^{*} X_{t+2}$ are 0.24 and -0.23 with p-values of 0.444 and 0.413 . Taken together these four estimates suggest that the ability of profit firms' stock returns to anticipate future earnings changes - as shown in Column (3) - is neither linked to nor improved by profit predictions in the annual report discussion section.

We make a very different set of observations for loss firms. First, for low disclosure loss firms there is no significant association between current stock returns and future earnings changes. The coefficients on $X_{t+1}+\operatorname{LOSS} * X_{t+1}$ and $X_{t+2}+\operatorname{LOSS} * X_{t+2}$ are -0.14 and -0.42 with pvalues of 0.587 and 0.516 (not reported in Table 3). Second, the incremental effect of disclosure for loss firms is significant, at least for one-period-ahead earnings. The coefficient on $D^{*} X_{t+1}+D^{*} L O S S * X_{t+1}$ is 0.88 with a p-value of 0.030 . Third, for high disclosure loss firms the coefficient on next period's earnings change of $0.74=-0.14+0.88$ is highly significant with a p-value of 0.018 (not reported in Table 3). Taken together the three observations are consistent with the view that the market has difficulties in predicting and valuing loss firms' future earnings potential, but that this difficulty can be overcome, at least in part, by providing profit-related trading statements in the annual report discussion section. That the incremental effect of disclosure is only significant in relation to next period's earnings change is perhaps not too surprising given that forward-looking statements in the annual report rarely refer to periods 
beyond period $t+1$. Note that there is no evidence in Table 3 that forward-looking profit statements are less informative in loss-making years.

[Table 3 about here]

In summary, the regression results in Table 3 suggest that narrative profit predictions in the annual reports of loss firms - but not those in the annual reports of profit firms - improve the ability of stock returns to anticipate next period's earnings information. However, statistically the incremental effect of profit predictions on prices leading earnings in Table 3 is not different between profit and loss firms. The p-value associated with $D^{*} \operatorname{LOSS} * X_{t+1}$ is not significant at conventional levels.

A potential problem with our results in Table 3 is that they ignore intrinsic differences in the predictability and timeliness of earnings across firms. Firms with more predictable and/or less timely earnings should exhibit a higher association between current returns and future earnings changes, and this effect is independent of disclosure. If predictability and timeliness vary systematically across our four subsamples in Column (5), then our regression results in Table 3 might underestimate (or overestimate) the association between disclosure and prices leading earnings and any difference in this association between profit and loss firms. To control, at least in part, for the cross-sectional variation in the intrinsic lead-lag relation between returns and earnings, we assign our sample firms to 30 Datastream Level 4 industry sectors and allow the coefficients on $X_{t}, X_{t+1}$ and $X_{t+2}$ to vary across industry. Gelb and Zarowin (2002) argue that combining firms by industry helps to isolate the effect of disclosure on share price anticipation of earnings because it eliminates inter-industry differences in accounting and real business factors. 
Industry-controlled results are reported in Table 4. Table 4 is similar to Table 3 but reports median coefficients (and no p-values) where parameters estimates are allowed to vary across industries. In relation to Columns (2), (3) and (4) we find that the coefficients are quite similar to the corresponding estimates in Table 3 , though the median coefficients on $X_{t}, X_{t+1}$ and $X_{t+2}$ tend to be higher than the (average) estimates in Table 3. Also, the coefficients on next period's return, $R_{t+1}$, are now all negative, as predicted by Collins et al. (1994).

When looking at our main regression results in Column (5) we note that the coefficient on $D^{*} X_{t+1}$ continues to be insignificant. This means that there is still no incremental effect of disclosure on share price anticipation of earnings for profit firms. This contrasts with loss firms for which we now obtain a much larger (and more significant) coefficient on $D * X_{t+1}+D * \operatorname{LOSS} * X_{t+1}$. Crucially, the incremental effect of disclosure on prices leading earnings (by one period) is now significantly greater for loss firms. The coefficient on $D * L O S S * X_{t+1}$ of 1.43 is highly significant. Based on this result we reject our null hypothesis $\mathrm{H}_{0}$. Overall, it appears that our failure to control for accounting and business factors leads to an underestimation of the differential effect of disclosure on prices leading earnings in Table 3 . Once again there is no evidence that narrative profit predictions are less informative in lossmaking years. ${ }^{15}$

\section{[Table 4 about here]}

Table 5 reports a number of specification checks on the regression results in Column (5) of Table 4 (which we regard as our main set of results). The first set of tests in Columns (2a), (2b) and

\footnotetext{
${ }^{15}$ The results in Table 4 are unaffected by the decision not to allow the intercept, the two return coefficients and the asset growth coefficient to vary across industry. If we allow these four coefficients to vary (in addition to the coefficients on the three earnings variables), then the resulting parameter estimates are similar to those reported in Table 4. In particular, the estimates on $D^{*} X_{t+1}$ and $D^{*} L O S S^{*} X_{t+1}$ in column (5) are 0.26 and 1.16 with p-values of 0.411 and 0.038 .
} 
(2c) involves using the full sample without dropping observations with disclosure scores in the two middle quartiles. The three columns differ in the definition of the disclosure dummy. In Column (2a) $D$ is set equal to 1 if the disclosure score falls into the top quartile of the distributions of disclosure scores, and 0 otherwise. We find that the coefficient on $D^{*} X_{t+1}$ continues to be insignificant, while the coefficient on $D^{*} \operatorname{LOSS} * X_{t+1}$ is now marginally significant. When we define the disclosure dummy as 1 for firms with disclosure scores in the bottom quartile of the distributions of disclosure scores (and 0 otherwise), then the coefficients on $D^{*} X_{t+1}$ and $D^{*} \operatorname{LOSS} * X_{t+1}$ in Column (2b) are both negative, as one would expect if firms with no (or little) profit predictions exhibit less share price anticipation of next period's earnings, and if this (negative) effect is larger for loss firms than for profit firms. However, neither coefficient is significant. Finally, in Column (2c) we define $D$ to be 1 for the top two quartiles of the distributions of disclosure scores (and 0 otherwise). The differential effect of disclosure on prices leading earnings between loss and profit firms now becomes very small.

We carry out one more test in relation to the disclosure dummy variable. We define two (rather than one) disclosure dummy variables, one for the top quartile of disclosure scores and another one for the two middle quartiles. The advantage of introducing two dummy variables is that the full sample of 4,568 observations is used in estimation, while the spread in the disclosure score between high and low disclosure firms is the same as that in Table 4. Consistent with our results in Column (5) of Table 4 we find that the incremental effect of disclosure on prices leading earnings by one period is small and insignificant for profit firms. The corresponding coefficient is 0.36 with a p-value of 0.237 . At the same time the differential effect of disclosure on prices leading earnings between loss and profit firms is 1.07 with a $\mathrm{p}$-value of $0.087 .^{16}$

\footnotetext{
${ }^{16}$ The regression results for this additional test are not reported in Table 5, but are available from the corresponding author upon request.
} 
Overall the specification tests so far indicate that our results are weaker when we reduce the spread in the disclosure score between high and low disclosure firms. We believe this is hardly surprising. Narrowing the difference in the disclosure score is likely to reduce the power of our test. However, when we use the full sample but hold the spread between high and low disclosure firms constant, then the differential effect of disclosure on prices leading earnings between loss and profit firms remains (marginally) significant.

The second set of specification checks relates to the treatment of outliers. As discussed in Section 5 we define outliers as observations falling into the top and bottom $1 \%$ of any of the seven regression variables, and for this definition we treat profit and loss observations as separate distributions. To examine the robustness of our results to the definition of outliers we define outliers in two other ways. First, in Column (3a) we define a constant cut-off point for profit and loss firms. In particular, we define outliers as observations with an absolute amount greater than 0.5 for deflated (current and future) earnings change and asset growth, and greater than 0.85 for (current or future) returns. Second, in Column (3b) we define outliers according to the DFFITS statistic. The DFFITS statistic measures the change in the predicted value that results from dropping a particular observation (Maddala, 2001: 476). A large value indicates that the observation is very influential. We use the size-adjusted cut-off point of $2 \sqrt{n / p}$ recommended by Belsley et al. (1980), where $n$ and $p$ are the number of observations and parameter estimates, respectively.

We find that the results in Columns (3a) and (3b) are similar to those in Column (5) of Table 4. In particular, the coefficient on $D^{*} X_{t+1}$ is close to zero, while the estimate on $D^{*} \operatorname{LOSS} * X_{t+1}$ continues to be significant at the $5 \%$ level. 
Our final specification test is reported in Column (4) of Table 5. We note in Section 5 that the median profit-making firm is almost five times as large as the median loss-making firm. At the same time the Pearson correlations in Table 2 indicate that disclosure is positively associated with firm size. Thus, it is possible that our regression results reflect the fact that there is less information available for smaller firms, making accounting narratives more important than for large firms. To investigate whether our regression results are driven by size differences (rather than the sign of current income) we match each loss firm with a profit firm of similar size. Given our earlier results we also match on industry.

Controlling for size (and industry) reduces the number of available observations substantially. However, despite the reduced sample size our main findings still hold. The coefficient on $D * X_{t+1}$ is negative, but insignificant, while the size of the coefficient on $D * \operatorname{LOSS} * X_{t+1}$ is very similar to that in Table 4 . Thus, it appears that differences in firm size are unlikely to explain our findings.

\section{[Table 5 about here]}

\section{Conclusion}

The current paper extends prior research into the association between disclosure quality and share price anticipation of earnings by discriminating between firms that report profits and firms that report losses. As a measure of disclosure quality we count the number of forward-looking profit statements in annual report narratives. To measure the extent to which current share price movements anticipate future earnings changes we regress current stock returns on current and future earnings changes. The coefficients on the future earnings change variables are our measure of share price anticipation of earnings. 
Our regression results show that the association between annual report narratives and share price anticipation of earnings is not the same for profit and loss firms. For loss firms we find that the ability of stock returns to anticipate next period's earnings change is significantly greater when the firm provides a large number of profit predictions in annual report narratives. We make no such observation for profit firms. In addition, once we control for variations in the intrinsic leadlag relation between returns and earnings across industries, the observed difference between profit and loss firms becomes statistically significant. Overall, our results are consistent with annual report narratives being a particularly important source of information for loss-making firms.

Two caveats apply to our research. First, our findings are conditional on a sufficiently large spread in the disclosure score between high and low disclosure firms. Second, our regression results do not provide direct evidence on whether accounting narratives themselves are informative in loss-making years, or whether accounting narratives are correlated with some other information that actually moves stock returns. For example, annual report narratives may serve as a confirmatory role for more informal information releases by the firm.

The current paper is the first to study the usefulness of narrative disclosures of loss-making firms. As such the results should be viewed as subject to future refinement. We believe that our research design could be fruitfully extended in at least two ways. First, future research could examine whether the identified effects vary systematically across industries or between singleloss and multiple-loss firms. Given the results in Ertimur (2004) one would expect the effect to be strongest in cases of firms (and industries) with multiple losses. Second, future work should seek to group firms according to indicators of the quality of their informal information flows and whether or not firms are paying dividends - hence opening up the possibility of dividend signalling as an alternative to disclosure. Unfortunately, conducting such additional tests will 
almost certainly require samples of loss-making firms that are larger than those employed in the current paper. 


\section{References}

Abrahamson, E. and Amir, E. (1996). 'The information content of the president's letter to shareholders'. Journal of Business, Finance and Accounting, 23 (8): 1157-82.

Baginski, S. P., Hassell, J.M. and Hillison, W.A. (2000). 'Voluntary causal disclosures: tendencies and capital market reaction'. Review of Quantitative Finance and Accounting, 15 (4): pp. 371-89.

Baginski, S. P., Hassell, J.M. and Kimbrough, M.D. (2004). 'Why do managers explain their earnings forecasts?'. Journal of Accounting Research, 42 (1): pp. 1-29.

Barron, O. E., Kile, C. O. and O'Keefe, T. B. (1999). 'MD\&A quality as measured by the SEC and analysts' earnings forecasts'. Contemporary Accounting Research, 16 (1): 75-109.

Belsley, D. A., Kuh, E. and Welsch, R. E. (1980). Regression Diagnostics. New York: John Wiley \& Sons, Inc.

Botosan, C. (1997). 'Disclosure level and the cost of equity capital'. Accounting Review, 72 (3): 323-49.

Bryan, S. (1997). 'Incremental information content of required disclosures contained in management discussion and analysis'. The Accounting Review, 72 (2): 285-301.

Clarkson, P. M., Kao, J. L. and Richardson, G. D. (1994). 'The voluntary inclusion of forecasts in the MD\&A section of annual reports'. Contemporary Accounting Research, 11 (1): 423-450.

Clarkson, P. M., Kao, J. L. and Richardson, G. D. (1999). 'Evidence that management discussion and analysis (MD\&A) is a part of a firm's overall disclosure package'. Contemporary Accounting Research, 16 (1): 111-134.

Clatworthy, M. and Jones, M. J. (2003). 'Financial reporting of good news and bad news: Evidence from accounting narratives'. Accounting and Business Research, 33 (3): 171-85.

Collins, D. W., Kothari, S. P., Shanken, J. and Sloan, R. G. (1994). 'Lack of timeliness and noise as explanations for the low contemporaneous return-earnings association'. Journal of Accounting and Economics, 18 (3): 289-324.

Ertimur, Y. (2004). 'Accounting Numbers and Information Asymmetry: Evidence from Loss Firms'. Working paper, Stanford University.

Frazier, K. B., Ingram, R. W. and Tennyson, B. M. (1984). 'A methodology for the analysis of narrative accounting disclosures'. Journal of Accounting Research, 22: 318-31.

Gelb, D. S. and Zarowin, P. (2002). 'Corporate disclosure policy and the informativeness of stock prices'. Review of Accounting Studies, 7: 33-52.

Hayn, C. (1995). 'The information content of losses'. Journal of Accounting and Economics, 20 (2): $125-153$. 
Hussainey, K., Schleicher, T. and Walker, M. (2003). 'Undertaking large-scale disclosure studies when AIMR-FAF ratings are not available: the case of prices leading earnings'. Accounting and Business Research, 33 (4): 275-294.

Hutton, A. P., Miller, G. S. and Skinner, D. J. (2003). 'The role of supplementary sentences with management earnings forecasts'. Journal of Accounting Research, 41 (5): 867-890.

Kothari, S. P. (1992). 'Price-Earnings Regressions in the Presence of Prices Leading Earnings'. Journal of Accounting and Economics, 15 (2): pp. 173-202.

Kothari, S. P. and Sloan, R. G. (1992). 'Information in prices about future earnings: implications for earnings response coefficients'. Journal of Accounting and Economics, 15 (2): 143-71.

Lennox, C. (2001). 'Self-serving disclosures by chairpersons of failing UK companies'. AsiaPacific Journal of Accounting and Economics, 8 (2): 63-81.

Lin, S. and Walker, M. (2000). 'FRS3 earnings, headline earnings, and accounting-based valuation models'. Accounting and Business Research, 30 (4): 299-306.

Lundholm, R.J. and Myers, L.A. (2002). 'Bringing the future forward: the effect of disclosure on the returns-earnings relation'. Journal of Accounting Research, 40 (3): 809-39.

Maddala, G. S. (2001). Introduction to Econometrics. Chichester: John Wiley \& Sons Ltd., 3rd edition.

Miller, G. and Piotroski, J. (2000). 'Forward-looking earnings sentences: determinants and market response'. Working paper, Michigan Business School.

Schleicher, T. and Walker, M. (1999). 'Share price anticipation of earnings and management's discussion of operations and financing'. Accounting and Business Research, 29 (4): 321-35.

Smith, M. and Taffler, R. (2000). 'The chairman's statement: A content analysis of discretionary narrative disclosures'. Accounting Auditing \& Accountability Journal, 13 (5): 624-46.

Steele, A. (1982). 'The accuracy of chairman's non-quantified forecasts: An exploratory study'. Accounting and Business Research, 12 (2): 215-30.

Tennyson, B.M., Ingram, R.W. and Dugan, M.T. (1990). 'Assessing the information content of narrative disclosures in explaining bankruptcy'. Journal of Business Finance and Accounting, 17 (3): $391-410$. 
Table 1. Descriptive Statistics.

\begin{tabular}{|c|c|c|c|c|c|c|c|}
\hline Variable & Mean & Min. & $25 \%$ & Median & $75 \%$ & Max. & OBS \\
\hline \multicolumn{8}{|c|}{ Panel A: Loss-making firm-years } \\
\hline$R_{t}$ & -0.085 & -0.932 & -0.527 & -0.249 & 0.106 & 4.867 & 324 \\
\hline$X_{t}$ & -0.035 & -1.489 & -0.109 & -0.012 & 0.024 & 1.428 & 324 \\
\hline$X_{t+1}$ & 0.059 & -0.425 & -0.006 & 0.016 & 0.086 & 1.513 & 324 \\
\hline$X_{t+2}$ & 0.034 & -0.545 & -0.014 & 0.010 & 0.059 & 0.737 & 324 \\
\hline$R_{t+1}$ & -0.001 & -0.912 & -0.484 & -0.116 & 0.215 & 4.307 & 324 \\
\hline$R_{t+2}$ & 0.211 & -0.926 & -0.333 & 0.000 & 0.457 & 4.301 & 324 \\
\hline$A G_{t}$ & 0.220 & -0.708 & -0.205 & -0.052 & 0.128 & 7.254 & 324 \\
\hline Total Assets (£m) & 1196 & 0.3 & 6.6 & 22.0 & 77.1 & 171699 & 324 \\
\hline Disclosure $=$ Low & 0.0 & 0 & 0 & 0 & 0 & 0 & 150 \\
\hline Disclosure $=$ High & 7.6 & 5 & 5 & 6 & 8 & 21 & 174 \\
\hline \multicolumn{8}{|c|}{ Panel B: Profit-making firm-years } \\
\hline$R_{t}$ & 0.115 & -0.685 & -0.168 & 0.044 & 0.315 & 2.224 & 2122 \\
\hline$X_{t}$ & 0.010 & -0.208 & -0.010 & 0.008 & 0.027 & 0.451 & 2122 \\
\hline$X_{t+1}$ & -0.001 & -0.355 & -0.019 & 0.005 & 0.025 & 0.266 & 2122 \\
\hline$X_{t+2}$ & -0.003 & -0.442 & -0.022 & 0.004 & 0.025 & 0.285 & 2122 \\
\hline$R_{t+1}$ & 0.063 & -0.778 & -0.218 & 0.005 & 0.287 & 2.195 & 2122 \\
\hline$R_{t+2}$ & 0.081 & -0.829 & -0.201 & 0.031 & 0.307 & 2.242 & 2122 \\
\hline$A G_{t}$ & 0.164 & -0.417 & -0.003 & 0.077 & 0.208 & 2.352 & 2122 \\
\hline Total Assets (£m) & 1072 & 0.9 & 28.7 & 109 & 559 & 96197 & 2122 \\
\hline Disclosure $=$ Low & 1.2 & 0 & 1 & 1 & 2 & 2 & 1099 \\
\hline Disclosure $=$ High & 10.3 & 7 & 8 & 9 & 11 & 31 & 1023 \\
\hline
\end{tabular}

Table 1 presents descriptive statistics. Panel A (B) corresponds to the subsample of loss-making (profit-making) firm-years. Returns, $R_{t}, R_{t+1}$ and $R_{t+2}$ are calculated as buy-and-hold returns from eight months before the financial year-end to four months after the financial year-end. The earnings variables, $X_{t}, X_{t+1}$ and $X_{t+2}$, are defined as earnings change per share in periods $t, t+1$ and $t+2$ deflated by the share price four months after the end of the financial year $t-1$. Earnings is measured by Worldscope item 01250 which is operating income before all exceptional items. Asset growth, $A G_{t}$, is defined as the growth rate of total assets (Worldscope item 02999) in period $t$. Disclosure $=$ disclosure scores. Firm-years with a disclosure score in the first (fourth) quartile of the distributions of disclosure scores are defined as low (high) disclosure firm-years. Observations with disclosure scores in the second and third quartiles are not included in Panels A and B. 
Table 2. Pearson Correlations.

\begin{tabular}{|c|c|c|c|c|c|c|c|c|c|}
\hline & $R_{t}$ & $X_{t}$ & $X_{t+1}$ & $X_{t+2}$ & $R_{t+1}$ & $R_{t+2}$ & $A G_{t}$ & $\begin{array}{c}\text { Total } \\
\text { Assets }\end{array}$ & $\begin{array}{l}\text { Disclo- } \\
\text { sure }\end{array}$ \\
\hline$R_{t}$ & & $\begin{array}{c}0.335 \\
(0.001)\end{array}$ & $\begin{array}{c}0.218 \\
(0.001)\end{array}$ & $\begin{array}{c}0.038 \\
(0.079)\end{array}$ & $\begin{array}{c}0.082 \\
(0.001)\end{array}$ & $\begin{array}{l}-0.063 \\
(0.004)\end{array}$ & $\begin{array}{c}0.160 \\
(0.001)\end{array}$ & $\begin{array}{l}-0.004 \\
(0.844)\end{array}$ & $\begin{array}{l}-0.076 \\
(0.001)\end{array}$ \\
\hline$X_{t}$ & $\begin{array}{c}0.189 \\
(0.001)\end{array}$ & & $\begin{array}{c}0.050 \\
(0.022)\end{array}$ & $\begin{array}{l}-0.047 \\
(0.031)\end{array}$ & $\begin{array}{c}0.064 \\
(0.003)\end{array}$ & $\begin{array}{c}0.012 \\
(0.571)\end{array}$ & $\begin{array}{c}0.161 \\
(0.001)\end{array}$ & $\begin{array}{l}-0.046 \\
(0.036)\end{array}$ & $\begin{array}{l}-0.125 \\
(0.001)\end{array}$ \\
\hline$X_{t+1}$ & $\begin{array}{c}0.007 \\
(0.894)\end{array}$ & $\begin{array}{l}-0.189 \\
(0.001)\end{array}$ & & $\begin{array}{c}0.001 \\
(0.967)\end{array}$ & $\begin{array}{c}0.364 \\
(0.001)\end{array}$ & $\begin{array}{c}0.058 \\
(0.008)\end{array}$ & $\begin{array}{c}0.022 \\
(0.310)\end{array}$ & $\begin{array}{c}-0.012 \\
(0.568)\end{array}$ & $\begin{array}{l}-0.007 \\
(0.749)\end{array}$ \\
\hline$X_{t+2}$ & $\begin{array}{l}-0.067 \\
(0.230)\end{array}$ & $\begin{array}{c}-0.011 \\
(0.848)\end{array}$ & $\begin{array}{l}-0.055 \\
(0.320)\end{array}$ & & $\begin{array}{c}0.166 \\
(0.001)\end{array}$ & $\begin{array}{c}0.321 \\
(0.001)\end{array}$ & $\begin{array}{l}-0.057 \\
(0.009)\end{array}$ & $\begin{array}{c}0.006 \\
(0.796)\end{array}$ & $\begin{array}{r}0.030 \\
(0.169)\end{array}$ \\
\hline$R_{t+1}$ & $\begin{array}{l}-0.027 \\
(0.631)\end{array}$ & $\begin{array}{c}0.014 \\
(0.800)\end{array}$ & $\begin{array}{c}0.181 \\
(0.001)\end{array}$ & $\begin{array}{l}-0.007 \\
(0.895)\end{array}$ & & $\begin{array}{l}-0.001 \\
(0.982)\end{array}$ & $\begin{array}{c}0.001 \\
(0.969)\end{array}$ & $\begin{array}{c}0.003 \\
(0.893)\end{array}$ & $\begin{array}{l}-0.019 \\
(0.393)\end{array}$ \\
\hline$R_{t+2}$ & $\begin{array}{l}-0.212 \\
(0.001)\end{array}$ & $\begin{array}{c}0.022 \\
(0.695)\end{array}$ & $\begin{array}{l}-0.009 \\
(0.875)\end{array}$ & $\begin{array}{c}0.126 \\
(0.023)\end{array}$ & $\begin{array}{l}-0.047 \\
(0.398)\end{array}$ & & $\begin{array}{l}-0.108 \\
(0.001)\end{array}$ & $\begin{array}{c}-0.024 \\
(0.273)\end{array}$ & $\begin{array}{l}-0.019 \\
(0.383)\end{array}$ \\
\hline$A G_{t}$ & $\begin{array}{c}0.173 \\
(0.002)\end{array}$ & $\begin{array}{c}0.104 \\
(0.061)\end{array}$ & $\begin{array}{c}-0.110 \\
(0.048)\end{array}$ & $\begin{array}{l}-0.031 \\
(0.577)\end{array}$ & $\begin{array}{l}-0.222 \\
(0.001)\end{array}$ & $\begin{array}{l}-0.135 \\
(0.015)\end{array}$ & & $\begin{array}{c}0.011 \\
(0.602)\end{array}$ & $\begin{array}{l}-0.013 \\
(0.551)\end{array}$ \\
\hline $\begin{array}{l}\text { Total } \\
\text { Assets }\end{array}$ & $\begin{array}{l}-0.018 \\
(0.741)\end{array}$ & $\begin{array}{c}0.004 \\
(0.947)\end{array}$ & $\begin{array}{l}-0.026 \\
(0.636)\end{array}$ & $\begin{array}{l}-0.017 \\
(0.760)\end{array}$ & $\begin{array}{c}0.047 \\
(0.394)\end{array}$ & $\begin{array}{l}-0.033 \\
(0.553)\end{array}$ & $\begin{array}{l}-0.017 \\
(0.766)\end{array}$ & & $\begin{array}{c}0.272 \\
(0.001)\end{array}$ \\
\hline $\begin{array}{l}\text { Disclo- } \\
\text { sure }\end{array}$ & $\begin{array}{l}-0.154 \\
(0.005)\end{array}$ & $\begin{array}{l}-0.126 \\
(0.023)\end{array}$ & $\begin{array}{c}0.084 \\
(0.131)\end{array}$ & $\begin{array}{c}0.015 \\
(0.783)\end{array}$ & $\begin{array}{l}-0.080 \\
(0.153)\end{array}$ & $\begin{array}{c}0.052 \\
(0.355)\end{array}$ & $\begin{array}{l}-0.072 \\
(0.197)\end{array}$ & $\begin{array}{c}0.136 \\
(0.014)\end{array}$ & \\
\hline
\end{tabular}

Table 2 presents Pearson correlations. Correlations below (above) the diagonal correspond to the subsample of loss-making (profit-making) firm-years. P-Values are given in parentheses. All variables are as defined in Table 1. Observations with disclosure scores in the second and third quartiles of the distributions of disclosure scores are excluded when calculating the correlations in Table 2. 
Table 3. Regression results: all regression coefficients are restricted to be the same across industries.

\begin{tabular}{|c|c|c|c|c|}
\hline (1) & (2) & (3) & (4) & (5) \\
\hline \multirow[t]{2}{*}{ Intercept } & $0.07 * * *$ & $0.09 * * *$ & $0.10 * * *$ & $0.10^{* * *}$ \\
\hline & $(0.001)$ & $(0.001)$ & $(0.001)$ & $(0.001)$ \\
\hline \multirow[t]{2}{*}{$X_{t}$} & $1.16^{* * *}$ & $2.31 * * *$ & $1.16^{* * *}$ & $2.17 * * *$ \\
\hline & $(0.001)$ & $(0.001)$ & $(0.001)$ & $(0.001)$ \\
\hline \multirow[t]{2}{*}{$X_{t+1}$} & $0.66 * * *$ & $1.52 * * *$ & 0.43 & $1.44 * * *$ \\
\hline & $(0.003)$ & $(0.001)$ & $(0.153)$ & $(0.001)$ \\
\hline \multirow[t]{2}{*}{$X_{t+2}$} & 0.17 & $0.65 * * *$ & 0.21 & $0.71 * * *$ \\
\hline & $(0.338)$ & $(0.001)$ & $(0.389)$ & $(0.001)$ \\
\hline \multirow[t]{2}{*}{$R_{t+1}$} & 0.02 & -0.03 & 0.02 & -0.04 \\
\hline & $(0.518)$ & $(0.216)$ & $(0.537)$ & $(0.140)$ \\
\hline \multirow[t]{2}{*}{$R_{t+2}$} & $-0.12 * * *$ & $-0.13 * * *$ & $-0.12 * * *$ & $-0.12 * * *$ \\
\hline & $(0.001)$ & $(0.001)$ & $(0.001)$ & $(0.001)$ \\
\hline \multirow[t]{2}{*}{$A G_{t}$} & $0.12 * * *$ & $0.11 * * *$ & $0.12 * * *$ & $0.11 * * *$ \\
\hline & $(0.006)$ & $(0.008)$ & $(0.007)$ & $(0.009)$ \\
\hline \multirow[t]{2}{*}{ LOSS } & & $-0.16^{* * *}$ & & -0.06 \\
\hline & & $(0.001)$ & & $(0.463)$ \\
\hline \multirow[t]{2}{*}{$L O S S^{*} X_{t}$} & & $-1.73 * * *$ & & $-1.50 * * *$ \\
\hline & & $(0.001)$ & & $(0.001)$ \\
\hline \multirow[t]{2}{*}{$\operatorname{LOSS}^{*} X_{t+1}$} & & $-1.28 * * *$ & & $-1.58 * * *$ \\
\hline & & $(0.001)$ & & $(0.001)$ \\
\hline \multirow[t]{2}{*}{$L O S S^{*} X_{t+2}$} & & $-0.89 * *$ & & $-1.13^{*}$ \\
\hline & & $(0.017)$ & & $(0.093)$ \\
\hline \multirow[t]{2}{*}{$D$} & & & $-0.06 * * *$ & $-0.03^{*}$ \\
\hline & & & $(0.001)$ & $(0.083)$ \\
\hline \multirow[t]{2}{*}{$D * X_{t}$} & & & -0.02 & 0.36 \\
\hline & & & $(0.946)$ & $(0.308)$ \\
\hline \multirow[t]{2}{*}{$D * X_{t+1}$} & & & 0.51 & 0.24 \\
\hline & & & $(0.159)$ & $(0.444)$ \\
\hline \multirow[t]{2}{*}{$D * X_{t+2}$} & & & -0.07 & -0.23 \\
\hline & & & $(0.818)$ & $(0.413)$ \\
\hline \multirow[t]{2}{*}{$D^{*} L O S S$} & & & & $-0.22 * *$ \\
\hline & & & & $(0.021)$ \\
\hline \multirow[t]{2}{*}{$D * \operatorname{LOSS} * X_{t}$} & & & & -0.54 \\
\hline & & & & $(0.331)$ \\
\hline \multirow[t]{2}{*}{$D * L O S S * X_{t+1}$} & & & & 0.64 \\
\hline & & & & $(0.210)$ \\
\hline \multirow[t]{2}{*}{$D * \operatorname{LOSS} * X_{t+2}$} & & & & 0.73 \\
\hline & & & & $(0.345)$ \\
\hline$D^{*} X_{t+1} \underline{\text { PLUS }}$ & & & & $0.88 * *$ \\
\hline$D * L O S S * X_{t+1}$ & & & & $(0.030)$ \\
\hline$D * X_{t+2}$ PLUS & & & & 0.50 \\
\hline$D * \operatorname{LOSS} * X_{t+2}$ & & & & $(0.488)$ \\
\hline $\mathrm{R}^{2}$ & 10.57 & 16.26 & 11.01 & 17.02 \\
\hline OBS & 2446 & 2446 & 2446 & 2446 \\
\hline
\end{tabular}

Table 3 presents OLS regression results. All regression coefficients are restricted to be same across all firm-years. Heteroscedasticityconsistent p-values are given in parentheses. LOSS is defined as $1(0)$ for firms with negative (positive) income in period $t$ where income is defined as operating income before all (operating and non-operating) exceptional items as given by Worldscope item 01250. Disclosure scores are converted into dummy variables. Firms with a disclosure score in the top (bottom) quartile of the distributions are defined as high (low) disclosure firms. The dummy variable, $D$, is set equal to 1 (0) for high (low) disclosure firms. Observations with disclosure scores in the second and third quartiles are not used in estimations. All other variables are as defined in Table 1 . The significance levels (two-tail test) are: $*$ $=10$ percent, $* *=5$ percent, $* * *=1$ percent. 
Table 4. Regression results: regression coefficients on $X_{t}, X_{t+1}$ and $X_{t+2}$ are allowed to vary across industries.

\begin{tabular}{|c|c|c|c|c|}
\hline (1) & (2) & (3) & (4) & (5) \\
\hline Intercept & $\begin{array}{c}0.07 * * * \\
(0.001)\end{array}$ & $\begin{array}{c}0.09 * * * \\
(0.001)\end{array}$ & $\begin{array}{c}0.10 * * * \\
(0.001)\end{array}$ & $\begin{array}{c}0.10 * * * \\
(0.001)\end{array}$ \\
\hline$X_{t}$ & $\begin{array}{l}1.88 \\
\text { (NA) }\end{array}$ & $\begin{array}{l}2.56 \\
\text { (NA) }\end{array}$ & $\begin{array}{l}1.99 \\
\text { (NA) }\end{array}$ & $\begin{array}{l}2.38 \\
\text { (NA) }\end{array}$ \\
\hline$X_{t+1}$ & $\begin{array}{l}1.00 \\
\text { (NA) }\end{array}$ & $\begin{array}{l}1.74 \\
\text { (NA) }\end{array}$ & $\begin{array}{l}0.76 \\
\text { (NA) }\end{array}$ & $\begin{array}{l}1.82 \\
\text { (NA) }\end{array}$ \\
\hline$X_{t+2}$ & $\begin{array}{l}0.36 \\
\text { (NA) }\end{array}$ & $\begin{array}{l}0.55 \\
\text { (NA) }\end{array}$ & $\begin{array}{l}0.45 \\
\text { (NA) }\end{array}$ & $\begin{array}{l}0.69 \\
\text { (NA) }\end{array}$ \\
\hline$R_{t+1}$ & $\begin{array}{c}-0.01 \\
(0.957)\end{array}$ & $\begin{array}{c}-0.04 \\
(0.104)\end{array}$ & $\begin{array}{c}-0.01 \\
(0.957)\end{array}$ & $\begin{array}{l}-0.05^{*} \\
(0.057)\end{array}$ \\
\hline$R_{t+2}$ & $\begin{array}{c}-0.12 * * * \\
(0.001)\end{array}$ & $\begin{array}{c}-0.12 * * * \\
(0.001)\end{array}$ & $\begin{array}{c}-0.12 * * * \\
(0.001)\end{array}$ & $\begin{array}{c}-0.12 * * * \\
(0.001)\end{array}$ \\
\hline$A G_{t}$ & $\begin{array}{c}0.13 * * * \\
(0.005)\end{array}$ & $\begin{array}{l}0.12 * * * \\
(0.004)\end{array}$ & $\begin{array}{c}0.13 * * * \\
(0.005)\end{array}$ & $\begin{array}{c}0.12 * * * \\
(0.004)\end{array}$ \\
\hline$L O S S$ & & $\begin{array}{c}-0.18 * * * \\
(0.001)\end{array}$ & & $\begin{array}{c}-0.06 \\
(0.483)\end{array}$ \\
\hline$L O S S^{*} X_{t}$ & & $\begin{array}{c}-2.11 * * * \\
(0.001)\end{array}$ & & $\begin{array}{c}-1.86 * * * \\
(0.001)\end{array}$ \\
\hline$L O S S^{*} X_{t+1}$ & & $\begin{array}{c}-1.72 * * * \\
(0.001)\end{array}$ & & $\begin{array}{c}-2.63 * * * \\
(0.001)\end{array}$ \\
\hline$L O S S^{*} X_{t+2}$ & & $\begin{array}{c}-0.68 \\
(0.230)\end{array}$ & & $\begin{array}{c}-0.42 \\
(0.713)\end{array}$ \\
\hline$D$ & & & $\begin{array}{c}-0.06 * * * \\
(0.003)\end{array}$ & $\begin{array}{c}-0.03 \\
(0.128)\end{array}$ \\
\hline$D * X_{t}$ & & & $\begin{array}{c}-0.43 \\
(0.139)\end{array}$ & $\begin{array}{c}0.44 \\
(0.233)\end{array}$ \\
\hline$D * X_{t+1}$ & & & $\begin{array}{c}0.45 \\
(0.133)\end{array}$ & $\begin{array}{c}0.29 \\
(0.327)\end{array}$ \\
\hline$D^{*} X_{t+2}$ & & & $\begin{array}{c}-0.36 \\
(0.228)\end{array}$ & $\begin{array}{c}-0.19 \\
(0.533)\end{array}$ \\
\hline$D^{*} \operatorname{LOSS}$ & & & & $\begin{array}{r}-0.24 * * \\
(0.017)\end{array}$ \\
\hline$D * L O S S * X_{t}$ & & & & $\begin{array}{c}-0.55 \\
(0.348)\end{array}$ \\
\hline$D^{*} \operatorname{LOSS} * X_{t+1}$ & & & & $\begin{array}{l}1.43 * * \\
(0.024)\end{array}$ \\
\hline$D * L O S S * X_{t+2}$ & & & & $\begin{array}{c}-0.13 \\
(0.911)\end{array}$ \\
\hline $\begin{array}{l}D * X_{t+1} \underline{\text { PLUS }} \\
D * L O S S^{*} X_{t+1} \\
D * X_{t+2} \underline{\text { PLUS }} \\
D * L O S S^{*} X_{t+2}\end{array}$ & & & & $\begin{array}{c}1.72 * * * \\
(0.003) \\
-0.32 \\
(0.774)\end{array}$ \\
\hline $\begin{array}{l}\mathrm{R}^{2} \\
\text { OBS }\end{array}$ & $\begin{array}{l}13.56 \\
2446\end{array}$ & $\begin{array}{l}19.14 \\
2446\end{array}$ & $\begin{array}{l}14.00 \\
2446\end{array}$ & $\begin{array}{l}20.14 \\
2446\end{array}$ \\
\hline
\end{tabular}

Table 4 presents OLS regression results. Sample firms are assigned to 30 Datastream Level 4 industry sectors and the coefficients on $X_{t}, X_{t+1}$ and $X_{t+2}$ are allowed to vary across industry. All other regression coefficients are restricted to be same across all firm-years. Where estimates are allowed to vary, median coefficients (and no p-values) are reported. Otherwise, heteroscedasticity-consistent p-values are given in parentheses. All variables are as defined in Table 3 . The significance levels (two-tail test) are: $*=10$ percent, $* *=5$ percent, $* * *=1$ percent. 
Table 5. Regression results: specification tests.

\begin{tabular}{|c|c|c|c|c|c|c|}
\hline \multirow[b]{3}{*}{ (1) } & \multicolumn{3}{|c|}{$\begin{array}{c}\text { Alternative Definition of High and Low } \\
\text { Disclosure Firm-Years }\end{array}$} & \multicolumn{2}{|c|}{$\begin{array}{l}\text { Alternative Treatment of } \\
\text { Outliers }\end{array}$} & \multirow{3}{*}{$\begin{array}{c}\text { Size Control } \\
\begin{array}{c}\text { Samples } \\
\text { matched on } \\
\text { size }\end{array}\end{array}$} \\
\hline & $\begin{array}{l}\mathrm{D}=1 \text { if top } \\
25 \%, \mathrm{D}=0 \\
\text { otherwise }\end{array}$ & $\begin{array}{c}\mathrm{D}=1 \text { if } \\
\text { bottom } 25 \%, \\
\mathrm{D}=0 \\
\text { otherwise }\end{array}$ & $\begin{array}{l}\mathrm{D}=1 \text { if top } \\
50 \%, \mathrm{D}=0 \\
\text { otherwise }\end{array}$ & $\begin{array}{c}\text { Constant } \\
\text { Cut-off } \\
\text { point }\end{array}$ & $\begin{array}{c}\text { Outliers } \\
\text { defined via } \\
\text { DFFITS }\end{array}$ & \\
\hline & $(2 a)$ & $(2 b)$ & $(2 c)$ & (3a) & $(3 b)$ & \\
\hline \multirow[t]{2}{*}{ Intercept } & $0.10 * * *$ & $0.09 * * *$ & $0.10 * * *$ & $0.02 * *$ & $0.15 * * *$ & $0.12 * * *$ \\
\hline & $(0.001)$ & $(0.001)$ & $(0.001)$ & $(0.036)$ & $(0.001)$ & $(0.007)$ \\
\hline \multirow[t]{2}{*}{$X_{t}$} & 2.07 & 2.12 & 2.05 & 1.90 & 2.59 & $2.92 * * *$ \\
\hline & (NA) & (NA) & (NA) & (NA) & (NA) & $(0.001)$ \\
\hline \multirow[t]{2}{*}{$X_{t+1}$} & 1.57 & 1.65 & 1.44 & 0.95 & 1.45 & $2.39 * * *$ \\
\hline & (NA) & (NA) & (NA) & (NA) & (NA) & $(0.001)$ \\
\hline \multirow[t]{2}{*}{$X_{t+2}$} & 0.57 & 0.47 & 0.55 & 0.25 & 0.40 & $1.53 * * *$ \\
\hline & (NA) & (NA) & (NA) & (NA) & (NA) & $(0.005)$ \\
\hline \multirow[t]{2}{*}{$R_{t+1}$} & -0.03 & -0.03 & -0.03 & $0.04 *$ & $-0.06^{* * *}$ & -0.01 \\
\hline & $(0.138)$ & $(0.149)$ & $(0.129)$ & $(0.062)$ & $(0.001)$ & $(0.956)$ \\
\hline \multirow[t]{2}{*}{$R_{t+2}$} & $-0.12 * * *$ & $-0.11 * * *$ & $-0.11 * * *$ & -0.02 & $-0.10 * * *$ & $-0.16 * * *$ \\
\hline & $(0.001)$ & $(0.001)$ & $(0.001)$ & $(0.514)$ & $(0.001)$ & $(0.001)$ \\
\hline \multirow[t]{2}{*}{$A G_{t}$} & $0.09 * * *$ & $0.10 * * *$ & $0.10 * * *$ & $0.11 * *$ & $0.05^{* *}$ & 0.05 \\
\hline & $(0.001)$ & $(0.001)$ & $(0.001)$ & $(0.034)$ & $(0.042)$ & $(0.396)$ \\
\hline \multirow[t]{2}{*}{ LOSS } & $-0.15^{* * *}$ & $-0.21 * * *$ & $-0.12 * * *$ & $-0.14 * *$ & $-0.18 * * *$ & -0.12 \\
\hline & $(0.001)$ & $(0.001)$ & $(0.007)$ & $(0.006)$ & $(0.002)$ & $(0.205)$ \\
\hline \multirow[t]{2}{*}{$L O S S^{*} X_{t}$} & $-1.67 * * *$ & $-1.75 * * *$ & $-1.58 * * *$ & $-1.44 * *$ & $-1.89 * * *$ & $-2.92 * * *$ \\
\hline & $(0.001)$ & $(0.001)$ & $(0.001)$ & $(0.005)$ & $(0.001)$ & $(0.001)$ \\
\hline \multirow[t]{2}{*}{$L O S S^{*} X_{t+1}$} & $-1.88 * * *$ & $-1.62 * * *$ & $-1.77 * * *$ & $-1.42 * *$ & $-1.72 * * *$ & $-2.61 * * *$ \\
\hline & $(0.001)$ & $(0.001)$ & $(0.001)$ & $(0.016)$ & $(0.001)$ & $(0.001)$ \\
\hline \multirow[t]{2}{*}{$L O S S^{*} X_{t+2}$} & $-0.97 * * *$ & $-0.80 * * *$ & $-1.22 * * *$ & -0.40 & -1.22 & -1.25 \\
\hline & $(0.002)$ & $(0.002)$ & $(0.006)$ & $(0.631)$ & $(0.135)$ & $(0.140)$ \\
\hline \multirow[t]{2}{*}{$D$} & $-0.03 * *$ & 0.01 & -0.02 & -0.01 & $-0.06 * * *$ & 0.01 \\
\hline & $(0.044)$ & $(0.419)$ & $(0.172)$ & $(0.900)$ & $(0.002)$ & $(0.882)$ \\
\hline \multirow[t]{2}{*}{$D * X_{t}$} & $0.60 * *$ & 0.16 & 0.28 & 0.13 & -0.33 & -0.43 \\
\hline & $(0.041)$ & $(0.586)$ & $(0.278)$ & $(0.631)$ & $(0.399)$ & $(0.550)$ \\
\hline \multirow[t]{2}{*}{$D * X_{t+1}$} & 0.31 & -0.21 & $0.48 * *$ & 0.02 & 0.08 & -0.87 \\
\hline & $(0.240)$ & $(0.419)$ & $(0.039)$ & $(0.945)$ & $(0.758)$ & $(0.227)$ \\
\hline \multirow[t]{2}{*}{$D * X_{t+2}$} & -0.18 & 0.26 & -0.05 & $0.41 *$ & -0.13 & -0.54 \\
\hline & $(0.520)$ & $(0.239)$ & $(0.813)$ & $(0.090)$ & $(0.653)$ & $(0.533)$ \\
\hline \multirow[t]{2}{*}{$D * L O S S$} & $-0.13^{*}$ & $0.15^{*}$ & $-0.15^{* *}$ & $-0.17 * * *$ & $-0.16^{* *}$ & -0.19 \\
\hline & $(0.056)$ & $(0.074)$ & $(0.014)$ & $(0.006)$ & $(0.035)$ & $(0.119)$ \\
\hline \multirow[t]{2}{*}{$D^{*} \operatorname{LOSS}{ }^{*} X_{t}$} & -0.39 & 0.19 & -0.40 & -0.63 & 0.45 & 0.88 \\
\hline & $(0.294)$ & $(0.708)$ & $(0.280)$ & $(0.299)$ & $(0.463)$ & $(0.261)$ \\
\hline \multirow[t]{2}{*}{$D^{*} L O S S^{*} X_{t+1}$} & 0.75 & -0.51 & 0.17 & $1.43 * *$ & $1.26^{* *}$ & $1.56^{*}$ \\
\hline & $(0.107)$ & $(0.331)$ & $(0.682)$ & $(0.041)$ & $(0.047)$ & $(0.064)$ \\
\hline$D * L O S S * X_{t+2}$ & 0.84 & 0.48 & 0.95 & -0.43 & 0.66 & 0.38 \\
\hline & $(0.181)$ & $(0.599)$ & $(0.117)$ & $(0.662)$ & $(0.478)$ & $(0.737)$ \\
\hline$D * X_{t+1}$ PLUS & $1.06 * * *$ & -0.72 & $0.65^{*}$ & $1.45^{* *}$ & $1.34 * *$ & 0.69 \\
\hline$D * \operatorname{LOSS} \overline{* X_{t+1}}$ & $(0.005)$ & $(0.128)$ & $(0.059)$ & $(0.020)$ & $(0.014)$ & $(0.103)$ \\
\hline$D * X_{t+2}$ PLUS & 0.66 & 0.74 & 0.90 & -0.02 & 0.53 & -0.16 \\
\hline$D * \operatorname{LOSS} \widetilde{* X_{t+2}}$ & $(0.226)$ & $(0.405)$ & $(0.109)$ & $(0.982)$ & $(0.541)$ & $(0.843)$ \\
\hline $\mathrm{R}^{2}$ & 16.04 & 16.02 & 16.11 & 18.32 & 14.69 & 15.44 \\
\hline OBS & 4568 & 4568 & 4568 & 1868 & 2605 & 376 \\
\hline
\end{tabular}

Table 5 presents specification tests using OLS. The first set of tests in Columns (2a), (2b) and (2c) involves using the full sample without dropping observations with disclosure scores in the two middle quartiles. The three columns differ in the definition of the disclosure dummy. In Column (2a) $D$ is set equal to 1 if the disclosure score falls into the top quartile of the distributions of disclosure scores, and 0 otherwise. In 
Column (2b) $D$ is set equal to 1 if the disclosure score falls into the bottom quartile of the distributions of disclosure scores, and 0 otherwise. In Column (2c) $D$ is set equal to 1 for firms in the top two quartiles of the distributions of disclosure scores, and 0 otherwise. The second set of specification tests relates to the treatment of outliers. In Column (3a) we define outliers as observations with an absolute amount greater than 0.5 for $X_{t}, X_{t+1}, X_{t+2}$ and $A G_{t}$ and greater than 0.85 for $R_{t}, R_{t+1}$ and $R_{t+2}$. In Column (3b) outliers are defined according to the DFFITS statistic. We use the size-adjusted cut-off point of $2 \sqrt{n} / p$, where $n$ and $p$ are the number of observations and parameter estimates, respectively. In column (4) we match each loss firm with a profit firm of similar size (while holding the industry composition constant). In Columns (2a), (2b), (2c), (3a) and (3b) sample firms are assigned to 30 Datastream Level 4 industry sectors and the coefficients on $X_{t}, X_{t+1}$ and $X_{t+2}$ are allowed to vary across industry. All other regression coefficients are restricted to be same across all firm-years. Where estimates are allowed to vary, median coefficients (and no p-values) are reported. Otherwise, heteroscedasticity-consistent p-values are given in parentheses. All variables (other than the disclosure dummy) are as defined in Table 3 . The significance levels (two-tail test) are: $*=10$ percent, $* *=5$ percent, $* * *=1$ percent. 